\title{
"A Pint of Plain is Your Only Man": Masculinities and the Pub in Twentieth Century Irish Fiction
}

\author{
Loic Wright \\ University College Dublin, Ireland
}

Copyright (c) 2020 by Loic Wright. This text may be archived and redistributed both in electronic form and in hard copy, provided that the author and journal are properly cited and no fee is charged for access.

\begin{abstract}
Lee Dunne's Goodbye to the Hill (1965) follows the life of Paddy Maguire in the Dublin suburb of Ranelagh during the mid- $20^{\text {th }}$ century. As a Bildungsroman, Dunne's novel charts the rites of passage necessary for Maguire to take his place in society among his peers. An important rite of passage for Maguire is his entrance into Dublin pubs as a way of achieving the ideals of local hegemonic masculinity. J.P. Donleavy's novel The Ginger Man (1955) then chronicles the psychological breakdown of the protagonist Sebastian Dangerfield. His breakdown is marked by frantic visits to public houses around Dublin where he seeks solace and a sense of re-masculinisation from his anxieties. This essay argues how Irish pubs are depicted in $20^{\text {th }}$ century fiction as ideological vehicles charged with assimilating Irish men into the ranks of homosocial society, inculcating the ideals of local hegemonic masculinity. This essay also demonstrates how, as a space from which women were barred until the 1960s in Ireland, pubs were used as essential hubs for homosocial interaction and markers of Irish masculinity. When women were gradually allowed into pubs, their presence was often sanctioned with certain caveats, often conducive to regulating additional aspects of local hegemonic masculinity
\end{abstract}

Key Words. Alcohol, Pub, Masculinity, Irish Fiction.

Resumen. La novela Goodbye to the Hill (1965) de Lee Dune cuenta la vida de Paddy Maguire a mediados del siglo XX en Ranelagh, un barrio de la periferia de Dublín. Entendida como bildungsroman, la novela de Dunne traza los ritos de iniciación de Maguire previos a su entrada a la sociedad y a las relaciones sociales. Uno de estos ritos es el acercamiento de Maguire a los pubs de Dublín como forma de personificar los ideales de masculinidad hegemónica. Por otro lado, la novela de J.P. Donleavy The Ginger Man (1955) narra la crisis mental de su protagonista, Sebastian Dangerfield. Su crisis está marcada por visitas frenéticas a pubs de Dublín en los cuales busca consuelo y una sensación de re-masculinización para superar sus miedos. Este ensayo sostiene que la representación literaria de los pubs irlandeses en la ficción del siglo XX los presenta como vehículos ideológicos encargados de integrar a 
los hombres irlandeses en la sociedad homosocial por medio de la inculcación de ideales centrados en una masculinidad hegemónica de carácter local. Este ensayo también demuestra que los pubs en Irlanda eran usados como ejes esenciales de la interacción homosocial y como marcadores de la masculinidad irlandesa debido a la prohibición de acceso a las mujeres hasta los años 60 del siglo XX. El acceso y la presencia progresiva de las mujeres en los pubs obligaba a los hombres a adoptar ciertas medidas cautelares, lo que normalmente resultaba en una regulación de aspectos adicionales de la masculinidad hegemónica local.

Palabras clave. Alcohol, pub, masculinidad, ficción irlandesa.

\section{Introduction}

In The Ginger Man (1955), J.P. Donleavy chronicles the psychological breakdown of the protagonist, Sebastian Dangerfield, as he drinks his way through pubs across Dublin during the 1950s. Although enrolled as a law student at Trinity College, Dangerfield spends most of his time drinking in public houses with his friends until gradually, he is left to continue drinking alone. All the while his wife Marion struggles at home, saving the little money she can find in order to salvage a basic and frugal life for herself and their baby. Unable to articulate his growing anxieties following his service in the US army, Dangerfield's drinking becomes increasingly frequent and destructive to himself and to those around him. After his wife leaves, Dangerfield pawns his clothes and scrounges from friends to fund his drinking. Concurrently, his Post Traumatic Stress Disorder (PTSD) from his army service mounts, and he consequently looks to alcohol to numb his pains. During his periodic visits to the local Dublin pubs, Dangerfield experiences momentary instances of respite and solace from his PTSD. Dangerfield's claim that "it's only the sociability that makes me drink" (Donleavy 239) demonstrates his reliance on male bonding through drinking to salvage a sense of masculinity. Dangerfield, whose pub visits become more solitary and desperate, settles for fighting with men in pubs as a basic form of homosocial interaction and demonstrating masculine dominance. For Dangerfield, the Irish pub is an important site for remasculinisation and refuge from his anxieties.

In contrast to the social disintegration of Sebastian Dangerfield, Lee Dunne's novel Goodbye to the Hill (1965) depicts the coming-of-age of Paddy Maguire during the 1950s. One important marker of Paddy's youth is his attempt to take part in the rites of passage for homosocial assimilation in the eyes of his male peers on The Hill, in the Dublin suburb of Ranelagh. Maguire is always striving to achieve a new aspect of local hegemonic masculinity as presented to him by his peers Larry and Harry. One of the most important milestones for Paddy is his induction into the pubs in Dublin where he learns how to drink and behave in accordance with social expectations of him. Subsequently, he becomes adept at adopting these traits and assimilating into the ranks of patriarchy.

In this essay, through reading Donleavy and Dunne's novels, I will argue how the pub plays an important role in the formation and regulation of local hegemonic masculinities in $20^{\text {th }}$ century Ireland. Using Michel Foucault's theory of "The Heterotopia", I assert that, as an historically androcentric space, the importance of the pub is as a locus for rites of passage in homosocial bonding, where men are assimilated into local hegemonic masculinity. As an important biopolitical steppingstone for homosocial assimilation in the formative years of young men, the pub is used thereafter by characters seeking re-masculinisation when in crisis. I will also contend how, as women became gradually more accepted into Irish pubs, their 
presence was authorised only within certain parameters of existence conducive to upholding ideals of local hegemonic masculinities.

Indeed, as cultural and social laws excluding women from pubs begin loosening in the 1950s and 1960s, few of the people Dangerfield and Maguire encounter in the local pubs are women. Despite its heretofore androcentric populace, Dangerfield is ambivalent towards female presence in pubs and even relishes it. His interactions with these women in pubs, often limited to lascivious seductions, are indicative of a deep-seated desire for Sebastian to redemonstrate his heterosexual manhood, whereby many of the women he meets in these pubs serve as mere constructions of his heterosexual fantasies. When Maguire notices women in pubs, they are often sexually promiscuous or sex-workers, and are therefore equally as conducive to his performance of masculinity as his homosocial bonding with Larry and Harry.

While Dangerfield's narrative chronicles his breakdown, Maguire's demonstrates his assimilation and social development as a man in the working-class suburb of the eponymous Hill. The 1940s of Dangerfield and the 1950s of Maguire are different in many ways, however there are also many similarities. On their respective trajectories, both men develop close relationships with their local pubs. For Dunne, the pub is an important location for Paddy as a rite of passage on The Hill; a setting wherein he will learn the social cues and adopt masculine behaviours to be accepted as a man into the local hegemonic masculinity. On the other hand, Dangerfield falsely perceives the pub as a safe haven for him to recuperate from his growing anxieties and perceived shortcomings as a man.

Michel Foucault describes the concept of the "Heterotopia" as a location which provides for individuals "a hidden network that determines the way they confront one another" (The Order of Things xxi). Expounding on Foucault's concept, Allison Macleod has situated the pub in the Irish cultural context as embodying the function of the "Heterotopia". Macleod argues that as an "historically and culturally significant space in Ireland that is central to the performance of gender and ethnicity, the Irish pub is a locus for examining how Irish masculinities are produced and regulated. It operates as a microcosm for Irish society, and yet even as it reflects dominant society it contests it" (47). Taking note of Macleod's reading of Foucault's "Heterotopia", what I want to argue is that the pub serves as an ideological vehicle, an important rite of passage for men to adopt scripts of local hegemonic masculinity and in turn, perform these behaviours in order to assimilate as a man in the eyes of their peers. When women become gradually more included in pubs, their presence provides men with an additional opportunity to prove their adherence to heterosexual aspects of hegemonic masculinity.

In their novels, both J.P. Donleavy and Lee Dunne demonstrate how the pub serves as a central hub of masculine activity. Moreover, when Donleavy and Dunne depict the increasing inclusion of women in pubs, they do so in line with patriarchal narratives prevalent in the mid-century and proceed to authorise only particular state-sanctioned notions of femininity in the pub, often conducive to regulating and normalising ideals of hegemonic masculinity. Describing the actions of Paddy Riley in Anthony Cronin's The Life of Riley (1964), Colm Toibín notes that Riley's needs "are exact - he needs good company, reasonable sex, drink" (viii). In the pubs across male characters in $20^{\text {th }}$ century Irish literature find the answers to these needs in the form of homosocial company, women against which to demonstrate their heterosexuality, and an abundance of alcohol, all instrumental in achieving ideals of local hegemonic masculinity.

\section{The pub as a rite of passage and sanctuary: (re)forming masculinity}

Diarmaid Ferriter notes that heavy drinking in the mid-century formed "an affirmation of male identity" ("Drink and Society" 352). Many male protagonists in $20^{\text {th }}$ century Irish 
literature thus exhibit a belief in this elision between alcohol consumption and manhood. Patrick Kavanagh's protagonist in Tarry Flynn (1948), a struggling farmer and aspiring poet, spends his limited finances on pints of porter for himself and the village blacksmith, integrating himself into the pub's masculine economy. Anthony Cronin's Paddy Riley in The Life of Riley leaves his job in the Civil Service, resigning himself to poverty, in order to spend his days with friends in pubs across Dublin. In Frank O'Connor's Dutch Interior (1940), Gus Devane returns to Ireland from abroad and is disgusted by his peers' reliance on alcohol and cyclical patterns of male alcoholism and stagnation. Many of these male characters find their predecessor in the character of Farrington in Joyce's "Counterparts" short story in Dubliners (1914). I argue that much like Farrington, who seeks solace in the pub from his public emasculations, a recurring thread among many of the men in these novels is that they are rarely fulfilling their ambitions and often find themselves in moments of paralysis or crisis. Oftentimes these characters feel as though they fail to meet cultural expectations of their local hegemonic masculinity. Thus, these men, who feel they have been undermined or emasculated, seek re-masculinisation in the pub, an important location in their formative years of homosocial assimilation. With reference to this first instance of Foucault's 'Heterotopia,' the pub becomes a masculine rite of passage with its male-only populace, and functions as an Althusserian ideological state apparatus, a central location charged with inculcating and perpetuating dominant state-sanctioned ideals in its subjects. Raewyn Connell identifies this as "the moment of engagement", whereby boys become men by subscribing to the ideals of local hegemonic masculinity (122). After undergoing these rites of passage and the initial moment of integration into masculine society, this pub is thereafter used as a haven where men seek refuge to be re-masculinised by means of homosocial interaction.

Arthur Flannigan-Saint-Aubin notes that "masculinity has constantly to be proved and can at any time be taken away" (244). Moreover, referring to this need to prove manhood, Michael Kimmel argues that "men prove their manhood in the eyes of other men" (129). Lee Dunne's and J.P. Donleavy's novels Goodbye to the Hill and The Ginger Man depict the function of the pub as a location where men can prove their masculinity to their peers. Dunne's Goodbye to the Hill narrates Paddy's childhood to perceived maturity before he emigrates. As a Bildungsroman, Dunne's novel portrays the various steps, traditions, and rites of passage Paddy must undertake before becoming a man in Ranelagh in the mid-century. One of the most important steps which impacts his life is his debut in the Dublin pub scenes. Paddy is snuck into a pub at the age of sixteen by an older friend Harry Redmond - a popular rite of passage - and put into the snug while his friend orders Guinness and cider. That the underage Paddy is placed in the snug serves as a practical precaution to avoid the eyes of the barman, however it also copper-fastens his lower status in hierarchical masculinity that he should be placed in the same space newly afforded to women in Irish pubs. Paddy, who has not had his first drink, is not yet a fully-fledged man in the eyes of his contemporaries, and is therefore feminized, on account of his perceived lack of masculinity. Moreover, Redmond buys Paddy cider rather than Guinness, the latter of which is evidently reserved for seasoned drinkers, like Redmond who acknowledges that "it's an acquired taste" (Dunne 51). Only later does Paddy make an explicit point of visibly drinking Guinness in front of Redmond who subsequently asks archly, "pints now is it Maguire?" (51). Paddy's graduation to drinking Guinness, I want to argue, symbolises the final step in a working-class equivalent to the tradition of a debutant ball whereby Paddy is inducted to the masculinist society of drinking in the pub and thus learns his cues from the men around him. Demonstrating the need to prove masculinity before peers, Paddy's performance of drinking Guinness before Redmond marks an important coming-of-age moment for the young Paddy who learns this attribute from his peers and will continue to perform it in front of other men in the novel. 
Although Paddy himself has only recently been inducted into masculine society by beginning to drink alcohol, he notices the social value placed on particular patterns of behaviour and specific actions between men in the pub. He becomes increasingly anxious to prove his manhood by performing these manly actions and taking part in the "banter" between himself and the men. Valerie Hey claims that "working-class notions of masculinity were very much grounded in 'drinking deeply', which was both a sign and an expression of one's virility" (25). Drinking in the pub, and the social politics that come with it, certainly form important aspects to hegemonic masculinity on the eponymous Hill. Paddy seeks to fit in, therefore, with these concepts of rough and rugged manliness by drinking and consequently being seen, through the eyes of local men, as a drinker. Local hegemonic masculinity on The Hill is bound to this peer-surveillance of the expression of manhood, and it becomes poignantly clear that such perceptions of masculinity are a valued currency in Paddy's social circles.

Judith Butler avers that "acts and gestures, articulated and enacted desires create the illusion of an interior and organising gender core" (2549). Dictated by the surrounding constructions of masculinity, Paddy's actions exhibit this Butlerian performativity of gender. Once Paddy has established an understanding of what is expected of him as a man on The Hill, he begins performing these traits back to his peers until they are internalised and normalised in order to integrate into these social ranks. Larry, Paddy's mentor and colleague, is curious of the latter's sudden interest in drinking in pubs. The ensuing exchange is particularly telling about Paddy's desire to portray himself in line with local scripts of hegemonic masculinity: "I was tying up the bundle of letters when Larry came up the office. 'Do you drink Paddy?' I grinned at him. 'Does a fish swim?' [...] then we walked up into Grafton Street to this little pub that Larry used" (Dunne 63). Both Redmond and Larry represent forms of masculine authority and mentorship whom Paddy wants to impress and emulate. Kimmel's claim about performativity and peer surveillance is particularly relevant here, where the men seek to outdo one another in terms of manly anecdotes. Once under the influence of alcohol, Larry admits that he had his first drink at the age of fourteen. I argue, therefore, that there is an immediate masculine rivalry between Larry and Paddy in this boast about the former's early interest in drinking. Larry - who sees Paddy already adeptly integrating socially - seemingly attempts to bluff his way to a status of long-established manhood by telling Paddy he was even younger when he began drinking. It is clear then, that Paddy consequently looks to Larry as a mentor. Paddy's performativity is not limited to his friendship with Larry as I have already demonstrated that Paddy consciously ensures Harry Redmond is watching him as he graduates from drinking cider to Guinness.

The next step for Paddy is buying rounds of drinks for these men. I posit that the "rounds system" of buying drinks creates a cycle of reciprocity and commonality between the men at the bar, creating a masculine economy. Paddy then becomes obsessed with the idea of being seen to be involved in this masculine social exchange at the bar. "When the waitress brought the bill I grabbed it before Larry could get his hands on it" (Dunne 127). Assuming the role of paying for the drinks places Paddy in the position of breadwinner and provider, synonymous with masculine and patriarchal authority. Consequently, at this point, Maguire has fully integrated himself into the intricacies of homosocial exchange in the pub. His entry into the local hegemonic masculinity of The Hill is thus copper-fastened.

Michael Kimmel asserts; "think of how men boast to one another of their accomplishments - from their latest sexual conquest to the size of the fish they caught - and how we constantly parade the markers of manhood - wealth, power, status, sexy women - in front of other men, desperate for their approval" (129). Moreover, Kiesling notes that "to be powerful in the current gender order is, in part, to be heterosexual (720). Reflecting Kimmel and Kiesling's arguments, Dunne elides two pivotal components to hegemonic masculinity on 
The Hill through Harry Redmond; drinking and competitive boasting about virile heterosexuality. An important component to the conversations between men in the pub is the lewd discussions about sex, sexuality, and women. "His return to the boozer and the details of the ride and his own brand of poetry through the Guinness and the laughter that rocked him where he sat" (Dunne 82). Redmond embodies many of the ideal pillars of local hegemonic masculinity which he instils and imparts onto the young Paddy Maguire. As previously illustrated, it is from these authority figures that Paddy learns his cues most associated with dominant masculine tropes. It is therefore unsurprising that Paddy repeats these patterns making derogatory and misogynistic comments to Redmond about a recent sexual encounter. Paddy, returning from a new sexual experience involving sadomasochism tells Harry "this mot I know. Loves being beaten with a cane, she does. Terrific looking mot too" (Dunne 115). This over-exaggerated report of his new sexual partner stems from a desire to one-up his former mentor and demonstrate himself to be superseding Redmond in terms of sexual knowledge and experience, all the while drinking a pint of stout. While Paddy does indeed engage in a new sexual encounter with sadomasochist tones, he grossly overstates the extent of his newfound sexual experience. I assert, thus, that Paddy's altered report of this encounter stems from this desire to one-up Harry, however his exaggerations are deeply misogynistic towards Breeda's sexual preferences.

Eve Kosofsky Sedgwick interrogates the basic tenets of homosocial interaction as "patterns of male friendship, mentorship, entitlement, rivalry, and hetero- and homosexuality" (2466). While these principles are ever-present in the interactions between men inside and outside of the pub, they are heightened inside the atmosphere of the pub because of its maleonly patronage. Paddy Maguire's relationships with Harry Redmond and Larry exhibit these traits in their most overt form. Being inducted into local hegemonic masculinity by both Redmond and Larry performatively interpellates Paddy into the position of mentee, eager to please his superiors. As I have averred, the rivalry over who began drinking at an earlier age is suggestive of Larry's need to remind Paddy of his lower position on the totem pole of masculine hierarchy. Moreover, Paddy's derogatory comments about Breeda's sexual preferences to Harry however are motivated by his desire to impress his mentor and demonstrate his quick assumption of heterosexual masculine roles. Maguire is therefore content to spend his income on this project of integrating himself into the masculine ranks in the pub. This is also suggestive that those who desperately seek to conform to these norms of gender relations see the pub as a prime site to achieve this.

Once a character has had their first experience of homsociality by entering the rite of passage of drinking in the pub, they may return to the site in future, perceiving it as a site of re-masculinisation. When feeling undermined or emasculated, the pub therefore becomes a haven to re-integrate into masculine ranks for men unable to communicate these anxieties. A significant tenet of masculinity and male identity is the prohibition and suppression of emotion who are "often unable to provide emotional intimacy or personal care" (Adams and Coltrane 230). However, Jean Lipman-Blumen notes that men "can derive satisfaction for their intellectual, physical, political, economic, occupational, social, power, and status needs and in some circumstances their sexual needs-from other men" (16). As a male-only space then, the pub is a prime location for meeting these homosocial needs, reifying its important function in regulating local hegemonic masculinity. Hugh Brody's account of a fictional village in the west of Ireland demonstrates the function of the pub in this regard. Brody's analysis of the camaraderie is evident across multiple texts from the mid-century:

A drunken man in winter leans more heavily on the bar. He often seeks to draw another drinker or two to his side. Such a group creates a tight circle of privacy around itself - a privacy physically expressed by the arms they lay across another's 
shoulders ... despair is not expressed in discussion among the drinkers. Rather, they exchange silence as if it were words, and words in brief expression of the lonesomeness (33).

Symbolically reflected here, the Irish pub offers both a reconciliation of unshared emotions and a site of re-masculinisation to those who feel undermined by their inabilities to live up to state-sanctioned and culturally promoted ideals of hegemonic masculinity.

By providing a site for re-integration into homosocial exchanges, the pub is represented here as the first port-of-call for men in crisis. Consequently, it once more demonstrates Foucault's theory of "The Heterotopia", this time that of the "Crisis Heterotopia," whereby he notes that "there are privileged or sacred or forbidden places, reserved for individuals who are, in relation to society and to the human environment in which they live, in a state of crisis" (Of Other Spaces 2019). The function of these "Crisis Heterotopias" in this regard is to provide a sanctuary of those who have been undermined or emasculated and where they may re-assimilate.

The recurring prominence of the pub in this regard is evident in many novels from the Twentieth Century. In The Country Girls (1960), Edna O'Brien portrays the pub as an offsite location for Caithleen's father, Mr. Brady, to quell his anxieties at having his house remortgaged. Similarly, Mahoney in John McGahern's The Dark (1965), subdues his anxieties of emasculation with palliative drinking binges. Both of these patriarchs are akin to Patrick McCabe's Benny in The Butcher Boy (1992), and symbolise Rosa González-Casademont's argument that these representations of alcoholism are "closely linked to the crisis of patriarchal power, for the male alcoholic usually stands as a signifier for the ineffective, emasculated father figure" (192).

Sebastian Dangerfield in The Ginger Man is indeed a precursor to these men in his attempts to suppress his patriarchal emasculation with bouts of heavy drinking. Both for the rest of the Dubliners in the novel, and for Dangerfield himself, the pub is the fantasy of homosocial inclusivity and commonality which provides a respite from feelings of male anxiety. Echoes of Brody's description homosocial despair are evident in Donleavy's depiction of Dublin's "public houses filling with the huddled men wiping noses across sleeves" (Donleavy 278). Donleavy's protagonist Sebastian Dangerfield may see himself as being at odds with the interdependent huddled masses of Irish men, however his own periodical visits to public houses are symptomatic of a deep-seated crisis. His frantic visits to public houses represent frenzied attempts at masculine re-integration, and a desire to assimilate and socialise.

Although Dangerfield has just been issued a grant by the US Army, he ends up virtually penniless, waiting on a windfall of inheritance when his father dies. Therefore, unable to provide for Marion and his child, Dangerfield scrounges, manipulates, and bullies those around him to fund his palliative drinking binges. It becomes increasingly evident that these binges serve to numb a sense of patriarchal emasculation comparable to Brady and Mahoney. Edward Gondolf demonstrates this link between concepts of undermined manhood and alcohol abuse, noting that alcohol abuse "may be manifestations of an underlying need for power and control related to the abuser's perception or conception of masculinity" (282). Dangerfield symbolises this argument in both his violent subjugation of his wife Marion and his periodic abuse of alcohol. Dangerfield's alcohol abuse is a form of self-medication to quell his anxieties and nervous breakdown. Like many of his contemporaries, he finally leaves Ireland in favour of London. However, this emigration does not provide him with the escape or solace he craves. As the city where he met his wife Marion, London provokes recollections of his time with his now-estranged wife and child and consequently serves as a catalyst for the beginnings of his second nervous breakdown. 
William David Sherman suggests that Dangerfield is far from the "image of a middleaged man of the verge of psychic disintegration" (225). However, I counter Sherman's claim by arguing that the drastic shift in narrative structure at the end of the novel coupled with frequents hints at an approaching nervous breakdown throughout the novel suggest otherwise. Dangerfield's thoughts and actions become increasingly erratic and frantic and he makes repeated references to "Bedlam," referring to "bestial bedlam" before claiming "I'm a man for Bedlam" (Donleavy 342). Donleavy's parallel of the increasingly frantic narrative and the references to Bethlem, an infamous psychiatric hospital in London, are suggestive of Dangerfield's impending nervous breakdown and imply that he may have already spent some time at the hospital. Underlying Dangerfield's breakdown long before the onset of sudden panic at the end of the novel is the manner in which Donleavy structures the narrative. Considering that Dangerfield's life is narrated at various points from both the first person and third person perspectives further adds to this sense of disconnect and anxiety regarding the protagonist's mindset. Donleavy symbolises Dangerfield's mental breakdown with a breakdown in narrative cohesion and unity. Moreover, up until this point Dangerfield has also been awaking in sudden sweats and panics at night only to be comforted by his wife Marion before her departure. She tells him, "you were yelling a few nights ago, how do I get out of this. And another time you were screaming ... you can laugh but I think there's something serious at the root of it" (Donleavy 48). With modern terminology on conflict-induced anxieties, it becomes evident that the signs of Dangerfield's impending nervous breakdown are also attributable to PTSD experienced from his time in the US Army. Dangerfield, rather than openly addressing his anxieties spends the entirety of the novel laughing off his nightly outbreaks and rushing into public houses. As a location where he has learned masculine codes and scripts, he can socialise with other men and numb his manic episodes and re-assimilate into homosocial ranks. Resorting to begging and stealing, Dangerfield's binges ultimately stem from a desire to salvage a sense of his persona of masculinity which he feels has been undermined by anxiety attacks.

Dangerfield is a victim of his own shortcomings brought on by an inability to articulate his anxieties. For Dangerfield the way to articulate this crisis is in the only outlet emotionally available to men, outbursts of anger and alcoholic self-medication. However, his own crisis and consequent outbursts of anger and violence result in his oppressive behaviour against his wife Marion and their baby. Consequently, Dangerfield spends progressively less time at home and more time flirting with the few women he meets in pubs in Dublin.

\section{A stranger in the (public) house: women in pubs}

Jean Lipman-Blumen, discussing male-only clubs, argues that women are excluded as "they would dilute the atmosphere and function of these bastions of male homosociality" (30). With reference to pubs, women's gradual inclusion came with certain caveats, often that their presence be limited to fulfilling a role conducive to regulating local hegemonic masculinity. Indeed, by the 1960s women were marginally more accepted into pubs if they remained in the snug, a privately enclosed room adjacent to the bar in a pub. Physically close yet psychologically distant, the snug recalls Jonathan Dollimore's concept of "The Proximate". A site or object which is "adjacent and there-by related temporally or spatially" however "is often constructed as the other, and in a process that facilitates displacement" (Dollimore 33). Dollimore's argument is evident with reference to "the snug" and demonstrates one of these caveats for allowing female presences in pubs. This smaller room within the pub meant men could reify their masculinity by measuring themselves against what they were not, that is femininity, visibly marginalised in the snug. As I have argued above, the psycho-spatial significance of the gendered space of the snug forms an important component to measuring 
manhood or lack thereof when inducting Paddy Maguire into masculine ranks. Before the popular use of the snug as an authorised feminine space, however, female presence in Irish pubs was uncustomary. Paddy Riley's partner Bridget in Anthony Cronin's The Life of Riley refuses to enter local pubs. The women in Edna O'Brien's The Country Girls order their drinks through whispers in hotel bars. Miss Frost in The Ginger Man is acutely aware of the cultural politics of the pub and its effects on notions of feminine decency noting "so many people look down on a woman who goes into a public house" (Donleavy 197). Though laws were loosening female presences in the pub were still relatively uncommon. Indeed, Paddy Maguire is initially taken aback by the increased presence of women in pubs, noting "that was something I hadn't expected. You just didn't see all that many women in pubs in Dublin" (Dunne 163). The separateness yet adjacency to the rest of the men in the pub creates a certain otherness between men and women where the latter, viewed as quasi-exotic phenomena are treated as fetishized commodities, worthy of unequivocal male attention and gaze.

Sharon R. Bird suggests (129) that "men in homosocial groups both objectify and compete for women". Moreover, Valerie Hey argues that female presence in the maledominated arena of the pub often results in unwelcome sexual advances "because there exists in popular culture and practice a conception that pubs for the most part are male enclaves and that individual women who enter them are therefore "only after one thing"' (4). Furthermore, women are also often only assigned to the role of barmaid in the pub, serving the needs of the men in the pub and forming the "construction of male fantasies" (Hey 43). The objectification of women is evident in the pub scenes depicted in Dunne and Donleavy's novels, where women are viewed in terms of their transgression of gender boundaries in the pub. These women are therefore perceived to be both sexually and morally transgressive, and exist only to serve the desires of the men in the pub. Therefore, I want to argue that the gradual acceptance of women in Irish pubs is heavily contingent on their ability to provide men with an additional opportunity to prove another facet of local hegemonic masculinity, that is, heterosexuality.

In their novels, both Lee Dunne and J.P. Donleavy portray the male belief in this fallacious conclusion drawn between female presence in the pub and the certainty of sexual promiscuity. Both novels represent women in pubs as being sex-workers or sexually promiscuous, aligning them within prominent patriarchal narratives of female nonrespectability. "Any lone woman in a pub can be placed in the 'non-respectable' category for the historical reason that the only women who entered pubs openly were prostitutes, whose services were demanded by the male clientele" (Hey 34). As a formerly androcentric space, dominated by masculinist discourse, the pub's newfound permission of female presence must align femininity within these masculine discourses, whereby women must fulfil a specific role within male heterosexual fantasy. In Goodbye to the Hill Paddy Maguire is once more drinking with his colleague Larry in a pub and as they approach closing time Breeda Connell, an old friend of Larry's, arrives and encounters the two men. Throughout their interaction Dunne hints at a subtle underlying understanding between Larry and Breeda. After a brief drinking session in the pub the three return to her apartment in Merrion Square before Breeda engages in back-to-back sexual intercourse with Larry, Paddy, and Larry again. After Paddy engages in sexual intercourse with Breeda, Larry gives him a ten-pound note. Once Paddy leaves, he finds himself perplexed at how quickly the encounter escalated. He thinks to himself "I knew she liked me. Either that or she was some actress" (Dunne 112). Paddy's uncertainty, coupled with Larry's coy manoeuvres and monetary profligacy, implies that Breeda may be a sex-worker that Larry has employed for Paddy. This is not the only instance of Dunne depicting overt and open female sexuality and sex-work as synonymous with a woman's presence in the pub. When Paddy returns from visiting Mrs. Kearney in Wicklow he 
stops off in a pub and a woman enters alone. After they begin talking and flirting, she tells him "I'm a working girl, love. Ten shillings to you" (Dunne 155). Dunne's portrayal of the only two women in the novel who enter pubs as being sex-workers embodies Valerie Hey's argument concerning authorised forms of feminine presences in the androcentric space of the pub.

Similarly, Donleavy's depictions of female presences in the pub concern Hey's contention on the male gaze and the barmaid. On one of Sebastian Dangerfield's many drinking binges he enters a pub on the Vico Road in Dalkey. Upon ordering his whiskey he begins leering at Gertrude, the barmaid; "damn girl with her gold, cheap bracelets, earrings, damn pair of gold tits, squirting out money" (Donleavy 112). Dangerfield's only interactions with Gertrude are limited to ordering his drinks from her and staring at her in a lecherous manner. Therefore, underpinning this is a sentiment that women can only be allowed to exist within these parameters of fulfilling constructions of male sexual fantasies, particularly that they should be sexual available to the men who otherwise regularly populate the pub. Ultimately, female presences in the pub in these novels are only authorised when performing a role that is conducive to formulating and regulating important aspects of local hegemonic masculinity, in these cases, heterosexuality.

Moreover, Dunne and Donleavy's depictions are doubly problematic as they a convey a sense of corruption of male respectability at the hands of sexually promiscuous women infiltrating a heretofore androcentric space. Many of the women whom Dangerfield encounters in pubs are revealed to be employed in the Magdalene Laundries. While they are not the women incarcerated in The Laundries, Donleavy calls into question themes of female immorality and juxtaposes them with female presences in pubs. While both male protagonists are already of morally dubious character, their supposed victimisation at the hands of these women who enter pubs is reflective of continued discourses on the (im-)morality of women in $20^{\text {th }}$ century Ireland, particularly those who drank alcohol or failed to conform to statesanctioned ideals of femininity. Diarmaid Ferriter accounts for this, discussing how literature published by the Pioneers was "utterly unambiguous in asserting females succumbing to drink were infinitely worse than drunken men, particularly in the context of the home" (A Nation of Extremes 169). As women were culturally and legislatively re-positioned within the home from the 1920s onwards, female alcoholism, though statistically lower, was deeply denounced as detrimental the integrity of the home. Male alcoholism, albeit also denounced, was seemingly more normalised.

\section{Conclusion}

Stephen L. Rowen argues that "in the decades following the Great Famine, men were not only devastated by their inability to feed their families, but it almost seemed as if men were encouraged by a defeated culture to frequent the pub in a context that, at worst, viewed the abuse of alcohol, as a 'good man's weakness'" (243). More social freedom was afforded to men in these years both culturally and legally as primary breadwinners in the family. However, in these years of economic stagnation before the First Programme for Economic Expansion in 1958, men who were unable to achieve culturally promoted ideals of financial independence sought validation or sublimation elsewhere. While the pub certainly is often one of the primary loci for recreational and social time outside of working hours (Sabo 330), this refuge for men consequently became a rite of passage for young men to assume their integration into masculine society.

The pub has been a recurring location depicted in Irish literature. Works such as Joyce's Dubliners and Ulysses (1922) in the early $20^{\text {th }}$ century set a precedent for how pubs would be depicted as hubs for masculine homosocial exchange; as a site of refuge in the short 
story "Counterparts", and as locations where men can gather and interact, in the "Cyclops" chapter of Ulysses. More recent works of Irish literature from the late $20^{\text {th }}$ and early $21^{\text {st }}$ centuries demonstrate how the pub continues to be depicted thus. Works such as Roddy Doyle's Two Pints (2012) - a short story series centred on the conversations of two barflies discussing contemporary issues - continue to depict these homosocial politics at play in the pub. Moreover, Conor McPherson's The Weir (1997) and Kevin Barry's "Breakfast Wine" (2007), a play and a short story respectively, depict the social politics of men drinking at the bar before being interrupted by the entrance of a woman. The women's orders for a glass of wine - symbolic markers of the onset of the Celtic Tiger - stand against the men's pints of stout and further demonstrate how marginalised female presences in these pubs are perceived as transgressive and exotic by the gaze of the regular male patrons. While the use of the pub as a hub for masculine exchange has its roots in the sublimation of anxieties, its recurring use thus normalised and reified the perception of the pub as a place where men could seek a sense of re-masculinisation. The importance of men's relationships to the pub became inextricably bound to constructions of their local hegemonic masculinities, whether by forming and interpellating ideal masculine Irish men, or by re-masculinising those in crisis of emasculation. The function of the pub in this regard is two-fold. Firstly, as a rite of passage, to serve as a site for homosocial, masculine integration and assimilation. Secondly, as the original site of masculine assimilation, a location thereafter to numb or quell feelings of undermined manhood. Due to its androcentric populace, the pub in the Irish cultural context performs an important component for regulating dominant concepts of masculinity and femininity. Moreover, for men seeking to stifle feelings of sexual stagnation prevalent during the mid- $20^{\text {th }}$ century, the pub offered solace from feelings of sexual frustration or emasculation. For patriarchs, it also provided respite from domestic life, seeking to engage in homosocial bonding, free from the perceived constraints of domestic life.

However, when cultural laws became less strict, the permission of women entering the pub came with implicit caveats, whereby women could remain in a pub if they fulfilled a particular role, contributing to heteronormative aspects to local hegemonic masculinity. Women, therefore, could stay in pubs if they formed a either a reminder of the femininity against which men could measure their masculinity, or a construction of male sexual fantasy. Considering these relationships between male and female gender roles and the pub, I argue that the pub functions as what R. W. Connell calls an "agency of socialisation" (330). An ideological vehicle charged with assimilating young men into their gender role and an important steppingstone for a young man's assimilation into society as a fully-fledged man in the eyes of the state and his peers. As Rowen has demonstrated the beginning of this dependence on the pub for men has its roots in the years succeeding the Great Famine, the pub then became reified and normalised as an intrinsically male space and important marker of Irish hegemonic masculinity. This normalisation of these rituals is evident in the prevalence of the pub's importance to Irish men would continue as a recurring trope throughout literature of the Twentieth Century across socio-economic borders, demonstrating how regular alcohol consumption became understood as an axiom of Irish masculine identity.

\section{Works Cited}

Adams, Michele and Scott Coltrane. "Boys and Men in Families: The Domestic Production of Gender, Power and Privilege". The Handbook of Studies on Men and Masculinities. Eds. Michael S. Kimmel, Jeff Hearn, and Raewyn W. Connell. Thousand Oaks: Sage Publications, 2005. 230-248. 
Bird, Sharon R. "Welcome to the Men's Club: Homosociality and the Maintenance of Hegemonic Masculinity". Gender and Society 10. 2 (1996): 120-32.

Brody, Hugh. Inishkillane: Change and Decline in the West of Ireland. Goring-by-Sea: Allen Lane, 1973.

Butler, Judith. "From Gender Trouble". The Norton Anthology of Theory and Criticism, Second Edition. Ed. Vincent Leitch, et al. New York: W. W. Norton \& Company, 2001. 2540-2552.

Connell, Raewynn W. Masculinities. Cambridge: Polity, 1995.

Dollimore, Jonathan. Sexual Dissidence: Augustine to Wilde, Freud to Foucault. Oxford: Clarendon Press, 1991.

Donleavy, J.P. The Ginger Man. London: Little Brown Book Group, 1997.

Dunne, Lee. Goodbye to the Hill. Dublin: Wolfhound Press, 1985.

Ferriter, Diamaid. A Nation of Extremes: The Pioneers in Twentieth Century Ireland. Dublin: Irish Academic Press, 1999.

. "Drink and Society in Twentieth-Century Ireland". Proceedings of the Royal Irish Academy: Archaeology, Culture, History, Literature 115C (2015): 349-69.

Flannigan-Saint-Aubin, Arthur. "The Male Body and Literary Metaphors for Masculinity". Theorizing Masculinities. Ed. Michael Kaufman and Harry Brod. Los Angeles: Sage, 1994. 239-258.

Foucault, Michel. Of Other Spaces (1967), Heterotopias. 5 September 2019. https://foucault.info/documents/heterotopia/foucault.heteroTopia.en/

- The Order of Things: An Archaeology of the Human Sciences. London: Routledge, 2003.

Gondolf, Edward W. "Alcohol Abuse, Wife Assault, and Power Needs". Social Service Review 69. 2 (1995): 274-84.

González Casademont, Rosa. "Irish Drinking Culture on the Screen". National Identities and Imperfections in Contemporary Irish Literature. Ed. Luz Mar González-Arias. London: Palgrave Macmillan, 2017. 183-200.

Hey, Valerie. Patriarchy and Pub Culture, London: Tavistok, 1986.

Kiesling, Scott Fabius. "Homosocial Desire in Men's Talk: Balancing and Re-Creating Cultural Discourses of Masculinity". Language in Society 34. 5 (2005): 695-726.

Kimmel, Michael S. "Masculinity as Homophobia". Theorizing Masculinities. Eds. Michael Kaufman and Harry Brod. Los Angeles: Sage, 1994. 119-141.

Kosofsky Sedgwick, Eve. "From Between Men". The Norton Anthology of Theory and Criticism, Second Edition. Ed. Vincent Leitch et al. New York: W. W. Norton \& Company, 2001. 2466-2469.

Lipman-Blumen, Jean. "Toward a Homosocial Theory of Sex Roles: An Explanation of the Sex Segregation of Social Institutions". Signs 1. 3 (1976): 15-31.

Macleod, Allison. "Queer Bodies and Contested Space Within the Irish Pub in A Man Of No Importance and Garage". Canadian Journal of Film Studies 4. 1 (2015): 45-65.

Rowen, Stephen L. "The Treatment of Alcohol Dependence in Ireland". Studies: An Irish Quarterly Review. 92.367 (2003): 243-47.

Sabo, Don. "The Study of Masculinities and Men's Health: An Overview". The Handbook of Studies on Men and Masculinities. Eds. Michael S. Kimmel, Jeff Hearn and Raewyn W. Connell. Thosand Oaks: Sage, 2005.

Sherman, William David. “J. P. Donleavy: Anarchic Man as Dying Dionysian". Twentieth Century Literature 13. 4 (1968): 216-28.

Toibín, Colm. "Introduction”. The Life of Riley. Dublin: New Island Books, 2010. vii-ix. 
Loic Wright is a $\mathrm{PhD}$ candidate in the School of English, Drama and Film at University College Dublin (UCD). He holds a joint honours bachelor's degree in English and Spanish, and a Master's degree in Anglo-Irish Literature and Culture from UCD. His PhD research interrogates how concepts of masculinity and manhood were measured and promoted in midTwentieth Century Ireland through the lens of Irish fiction between 1930 and 1960. Loic also works at the James Joyce Cultural Centre in Dublin where he helps co-ordinate cultural events, workshops, and literary tours of Joyce's Dublin and the Irish literary tradition.

loic.wright@ucdconnect.ie 